\title{
CHLOROPHYLL FLUORESCENCE OF TROPICAL TREE SPECIES IN A SEMI-DECIDUOUS FOREST GAP ${ }^{1}$
}

\author{
Rafael Vasconcelos Ribeiro², Gustavo Maia Souza², Angelo Gilberto Manzatto ${ }^{3}$, Eduardo Caruso Machado ${ }^{4}$ \\ Ricardo Ferraz de Oliveira ${ }^{2}$
}

\begin{abstract}
The characterization of different ecological groups in a forest formation/succession is unclear. To better define the different successional classes, we have to consider ecophysiological aspects, such as the capacity to use or dissipate the light energy available. The main objective of this work was to assess the chlorophyll fluorescence emission of tropical tree species growing in a gap of a semi-deciduous forest. Three species of different ecological groups were selected: Croton floribundus Spreng. (pioneer, P), Astronium graveolens Jacq. (early secondary, $\mathrm{Si}$ ), and Esenbeckia febrifuga A. Juss. (late secondary, St). The potential $\left(\mathrm{F}_{\mathrm{v}} / \mathrm{F}_{\mathrm{m}}\right)$ and effective $\left(\Delta \mathrm{F} / \mathrm{F}_{\mathrm{m}}{ }^{\prime}\right)$ quantum efficiency of photosystem II, apparent electron transport rate (ETR), non-photochemical (qN) and photochemical $(\mathrm{qP})$ quenching of fluorescence were evaluated, using a modulated fluorometer, between 7:30 and 11:00 h. Values of $F_{v} / F_{m}$ remained constant in St, decreasing in $\mathrm{P}$ and Si after 9:30 h, indicating the occurrence of photoinhibition. Concerning the measurements taken under light conditions $\left(\Delta \mathrm{F} / \mathrm{F}_{\mathrm{m}}{ }^{2}, \mathrm{ETR}, \mathrm{qP}\right.$ and $\left.\mathrm{qN}\right), \mathrm{P}$ and Si showed better photochemical performance, i.e., values of $\Delta \mathrm{F} / \mathrm{F}_{\mathrm{m}}$, ETR and qP were higher than St when light intensity was increased. Values of $\mathrm{qN}$ indicated that $\mathrm{P}$ and $\mathrm{Si}$ had an increasing tendency of dissipating the excess of energy absorbed by the leaf, whereas the opposite was found for St. The principal component analysis (PCA), considering all evaluated parameters, showed a clear distinction between $\mathrm{St}, \mathrm{P}$ and $\mathrm{Si}$, with $\mathrm{P}$ and $\mathrm{Si}$ being closer. The PCA results suggest that chlorophyll fluorescence may be a potential tool to differentiate tree species from distinct successional groups.
\end{abstract}

Key words: Chlorophyll fluorescence, ecophysiology, successional classes, Croton floribundus, Astronium graveolens, Esenbeckia febrifuga.

\section{FLUORESCÊNCIA DA CLOROFILA DE ESPÉCIES ARBÓREAS TROPICAIS EM UMA CLAREIRA DE FLORESTA SEMIDECÍDUA}

\begin{abstract}
RESUMO - A caracterização dos diferentes grupos ecológicos envolvidos nos processos de formação/sucessão florestal é ainda pouco precisa. Para melhor distinção das classes sucessionais deve-se levar em consideração aspectos ecofisiológicos, como a capacidade de aproveitamento da energia luminosa. O objetivo deste trabalho foi acessar a emissão da fluorescência da clorofila de espécies arbóreas tropicais crescendo em uma clareira de floresta semidecídua. Foram selecionadas três espécies de diferentes grupos ecológicos: Croton floribundus Spreng. (pioneira, P), Astronium graveolens Jacq. (secundária inicial, Si) e Esenbeckia febrifuga A. Juss. (secundária tardia, St). A eficiência quântica potencial $\left(F_{\sqrt{ }} / F_{m}\right)$ e efetiva $\left(\Delta F / F_{m}{ }^{\prime}\right)$ do fotossistema II, a taxa aparente de transporte de elétrons (ETR) e os coeficientes de extinção fotoquímica (qP) e não-fotoquímica (qN) da fluorescência da clorofila foram avaliados, utilizando um fluorômetro modulado, entre 7 h30 e 11h. Os valores de $F, / F_{m}$ permaneceram constantes em St, diminuindo em $P$ e Si a partir das 9h30, indicando a ocorrência de fotoinibição. Entretanto, nas medidas realizadas na presença de luz $\left(\Delta F / F_{m}{ }^{\prime}, E T R, q P\right.$ e $\left.q N\right)$, P e Si apresentaram
\end{abstract}

\footnotetext{
Recebido para publicação em 13.11.2002 e aceito para publicação em 17.2.2004.

2 Departamento de Ciências Biológicas, Escola Superior de Agricultura "Luiz de Queiroz" - Universidade de São Paulo. Av. Pádua Dias, 11, Caixa Postal 09, 13418-900 Piracicaba-SP, Brasil, <rvribeir@ esalq.usp.br>. ${ }^{3}$ Departamento de Botânica, Instituto de Biociências - Universidade Estadual Paulista. Av. 24A, 1515, 13506-900 Rio Claro-SP, Brasil. ${ }^{4}$ Centro de Pesquisa e Desenvolvimento em Ecofisiologia e Biofísica, Instituto Agronômico, Av. Barão de Itapura, 1481, Caixa Postal 28, $13001-970$ Campinas-SP, Brasil.
} 
melhor desempenho fotoquímico, ou seja, com o aumento da intensidade luminosa os valores de $\Delta F / F_{m}{ }^{\prime}, E T R$ e $q P$ foram superiores aos valores de St. Os valores de qN indicaram que P e Si possuem a tendência crescente de dissipar o excesso de energia, sendo observado o contrário em St. A análise de componentes principais (PCA), considerando todos parâmetros avaliados, mostrou clara distinção entre St, P e Si, sendo estas últimas espécies mais próximas. Os resultados dessa análise evidenciam a fluorescência da clorofila como uma ferramenta potencial para diferenciar espécies arbóreas de grupos sucessionais distintos.

Palavras-chave: Fluorescência da clorofila, ecofisiologia, classes sucessionais, Croton floribundus, Astronium graveolens e Esenbeckia febrifuga

\section{INTRODUCTION}

Forest communities have been characterized as a successional mosaic with different structural and floristic phases. The forest dynamic and self-maintaining processes emerge from the different environments produced in that mosaic, where the species have different capacities to develop and survive despite the environmental changes (Gandolfi et al., 1995; Pickett \& Ostfeld, 1995).

Patterns of tropical succession and species replacement are shaped and determined by the dynamic nature of forests. Gap-phase succession in tropical forests is driven by changes in resource availability arising from canopy and soil disturbances. Concerning the resources, the differences in light quantity and quality between an undisturbed forest and a newly created gap play a crucial role influencing species establishment, growth and reproduction (Strauss-Debenedetti \& Bazzaz, 1996).

Some available criteria to distinguish the ecological groups, taking into account ecophysiological aspects, such as the capacity to use or dissipate light energy, are fundamental elements for the study of forest dynamics. Differences in the potential for acclimation and susceptibility to photoinhibition in new gaps may be critical in determining the establishment and competition between species groups (Krause et al., 2001). Energydependent quenching (part of non-photochemical quenching), as the main expression of non-radioactive energy dissipation at photosystem II (PSII) level, has been proposed to reflect down-regulation of (PSII) under excessive light (Weis \& Berry, 1987). This process has considerable importance for the survival of plants in a changing environment (Schreiber et al., 1998), such as a forest gap.

There are few studies involving the responses of different tropical tree species to a similar light regime, especially when forest gaps are considered. Therefore, the aim of this study was to assess the chlorophyll fluorescence emission of tropical tree species growing in a natural gap of a semi-deciduous forest in Rio Claro, SP, Brazil.

\section{MATERIALS AND METHODS}

Plants of Croton floribundus Spreng., Astronium graveolens Jacq. and Esenbeckia febrifuga A. Juss. were used to measure chlorophyll fluorescence. According to Gandolfi et al. (1995), C. floribundus was classified as a pioneer species, A. graveolens as an early secondary species, and E. febrifuga as a late secondary species. The study was carried out in a semi-deciduous forest located in Rio Claro, SP, Brazil. The plants, ranging from 0.5 to $1.2 \mathrm{~m}$ high, were growing under a forest gap condition. Photosynthetic photon flux density (PPFD) and air temperature $(\mathrm{T})$ were measured in the gap and outside of the forest throughout the morning (same times of chlorophyll fluorescence measurements) on March 2, 2002 (summer). PPFD was measured with a quantum sensor (Li-250, Li-Cor, Lincoln, NE USA) and T using a psychrometer (Psychro-dyne, IIS, Southampton, PA USA). Three completely-expanded leaves of each species were used for chlorophyll fluorescence measurements.

\subsection{Chlorophyll Fluorescence}

A PAM-2000 fluorometer (Walz, Effeltrich, Germany) and a special leaf clip holder (model 2030-B, Walz) were used. Measuring light and saturating light pulses were applied through a fiberoptics pointing at an angle of $60^{\circ}$ to the leaf. Maximal $\left(\mathrm{F}_{\mathrm{m}}\right)$ and basal $\left(\mathrm{F}_{\mathrm{o}}\right)$ fluorescence yield were measured in dark-adapted (30 min with leaf clip) leaves, whereas steady-state $\left(\mathrm{F}_{\mathrm{s}}\right)$ and maximal $\left(\mathrm{F}_{\mathrm{m}}{ }^{\prime}\right)$ fluorescence yields were sampled in light-adapted leaves (Van Kooten \& Snel, 1990). Variable fluorescence yield was determined in dark-adapted 
$\left(\mathrm{F}_{\mathrm{v}}=\mathrm{F}_{\mathrm{m}}-\mathrm{F}_{\mathrm{o}}\right)$ and light-adapted $\left(\Delta \mathrm{F}=\mathrm{F}_{\mathrm{m}}{ }^{\prime}-\mathrm{F}_{\mathrm{s}}\right)$ leaves. $\mathrm{F}_{\mathrm{o}}$ ' was the basal fluorescence yield after photosystem I excitation by far-red light. The parameters calculated were: potential $\left(\mathrm{F}_{\mathrm{v}} / \mathrm{F}_{\mathrm{m}}\right)$ and effective $\left(\Delta \mathrm{F} / \mathrm{F}_{\mathrm{m}}{ }^{\prime}\right)$ quantum efficiency of photosystem II (PSII) (Genty et al., 1989), photochemical (qP) and non-photochemical (qN) fluorescence quenching, and apparent electron transport rate (ETR), being $\mathrm{qP}=\left[\left(\mathrm{F}_{\mathrm{m}}{ }^{\prime}-\mathrm{F}_{\mathrm{s}}\right) /\left(\mathrm{F}_{\mathrm{m}}{ }^{\prime}-\mathrm{F}_{\mathrm{o}}{ }^{\prime}\right)\right], \mathrm{qN}=\left[1-\left(\mathrm{F}_{\mathrm{m}}{ }^{\prime}-\mathrm{F}_{\mathrm{o}}{ }^{\prime}\right) /\left(\mathrm{F}_{\mathrm{m}}-\mathrm{F}_{\mathrm{o}}\right)\right]$, and $\mathrm{ETR}=\left(\mathrm{PPFDx} \Delta \mathrm{F} / \mathrm{F}_{\mathrm{m}}{ }^{\prime} \mathrm{x} 0.5 \mathrm{x} 0.84\right)($ Bilger et al., 1995; Krall \& Edwards, 1992; Van Kooten \& Snel, 1990). For ETR calculation, 0.5 was used as the fraction of excitation energy distributed to PSII, and 0.84 was used as the fractional light absorptance. All measurements were taken at 7:30, 8:30, 9:30 and 11:00 h under natural light conditions. Leaf temperatures and PPFD incident at leaf $\left(\mathrm{PPFD}_{\mathrm{L}}\right)$ were measured with the leaf clip holder of the PAM-2000 system. Relative excessive PPFD was calculated as the difference between $\mathrm{F}_{\mathrm{v}} / \mathrm{F}_{\mathrm{m}}$ and $\Delta \mathrm{F} /$ $\mathrm{F}_{\mathrm{m}}$, , normalized by $\mathrm{F}_{\mathrm{v}} / \mathrm{F}_{\mathrm{m}}$, according to Bilger et al. (1995).

\subsection{Statistics}

Data were analyzed by principal component analysis (PCA) to separate the species in different groups taking into account all evaluated parameters. PCA is a linear dimensionality reduction technique that identifies orthogonal directions of maximum variance in the original data and projects the data into a lower-dimensionality space made of a sub-set of the highest-variance components (Manly, 1994; McGarigal et al., 2000). In this study, a space of two dimensions (two principal components), which was demarcated by two axes labeled pc1 and pc2, was suitable to our analysis. The software PC-ORD version 3.12 (MJM Software Design, Gleneden Beach, OR USA) was used.

\section{RESULTS AND DISCUSSION}

\subsection{Environmental Conditions}

At the highest PPFD value outside of the forest (Figure 1), the gap was submitted to $1 / 4$ of the total radiation, approximately $450 \mu \mathrm{mol} / \mathrm{m}^{2} / \mathrm{s}$. Since PPFD measurements were taken in a medium point between the sampled species, some plants had probably received some sunfleck during the measurement period. At outside and in forest gap air temperatures increased in $4.5^{\circ} \mathrm{C}$ during the morning (Figure 1).
Leaf temperature $\left(T_{L}\right)$, as well as incident PPFD in the leaf $\left(\mathrm{PPFD}_{\mathrm{L}}\right)$ showed some variation during the measurements. The highest values of both variables were observed at 11:00 h. $\mathrm{T}_{\mathrm{L}}$ ranged from 20 to $28^{\circ} \mathrm{C}$ in all species (data not shown), while PPFD $_{\mathrm{L}}$ reached $1100 \mu \mathrm{mol} / \mathrm{m}^{2} / \mathrm{s}$ (sunfleck) in A. graveolens. It is believed that PPFD was the principal environmental factor that affected the patterns of chlorophyll fluorescence emission by the evaluated species.

\subsection{Chlorophyll Fluorescence}

E. febrifuga maintained high values of $\mathrm{F}_{\mathrm{v}} / \mathrm{F}_{\mathrm{m}}$ throughout the measurements, whereas $C$. floribundus and $A$. graveolens showed low $\mathrm{F}_{\mathrm{v}} / \mathrm{F}_{\mathrm{m}}$ values at 11:00 h, with a greater drop from $9: 30 \mathrm{~h}$ in A. graveolens (Figure 2).

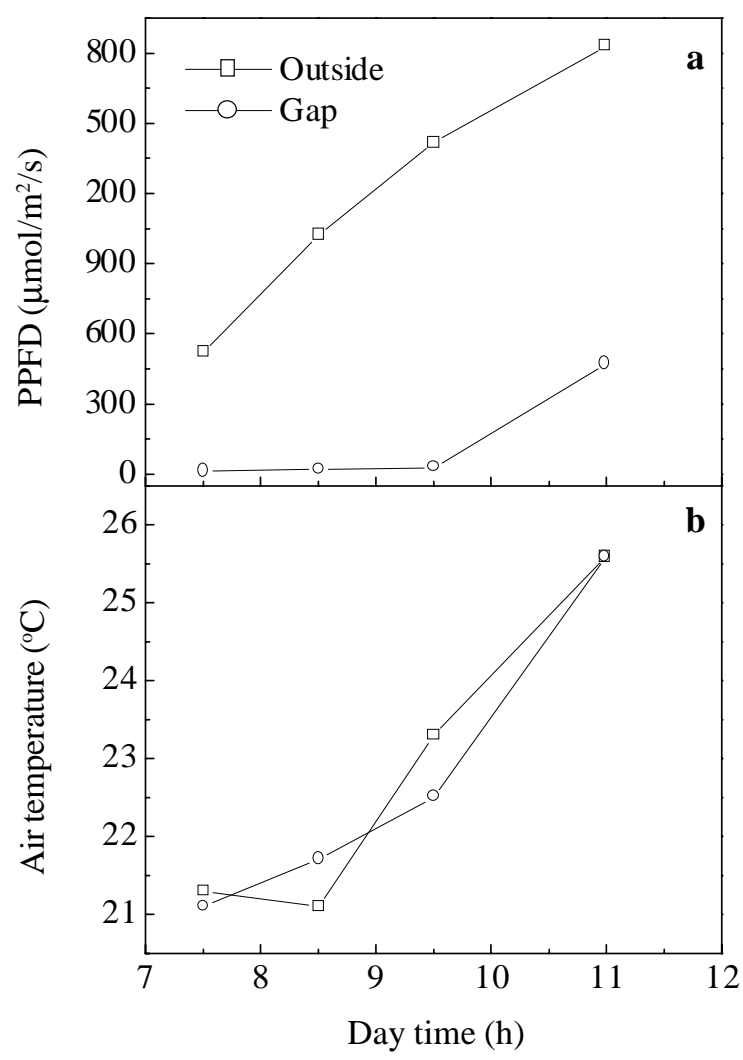

Figure 1 - Time course of photosynthetic photon flux density (PPFD, a) and air temperature (b) in a gap and outside of a semi-deciduous forest.

Figura 1 - Variação no decorrer da manhã da densidade de fluxo defótons fotossintéticos (PPFD, a) etemperatura do ar (b) na borda e clareira de uma floresta semidecídua.

R. Árvore, Viçosa-MG, v.28, n.1, p.21-27, 2004 


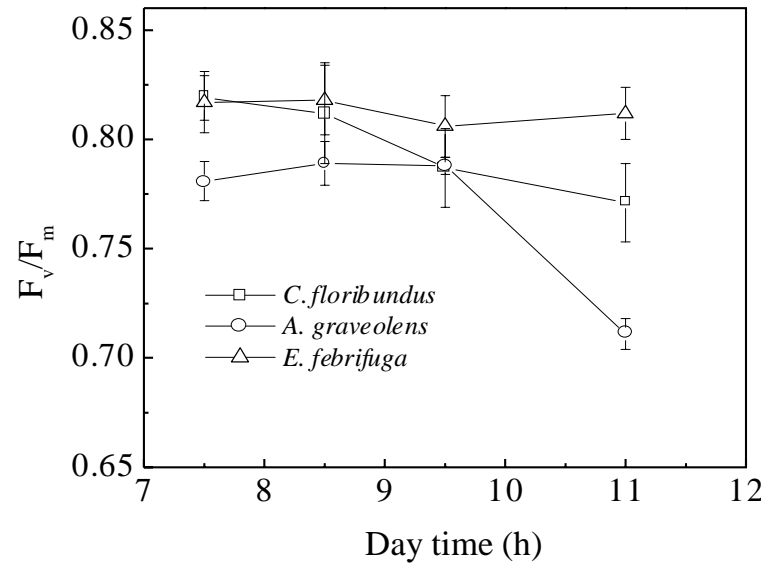

Figure 2 - Time course of potential quantum efficiency of PSII $\left(F_{N} / F_{m}\right)$ of $C$. floribundus, $A$. graveolens and E. febrifuga growing in a gap of a semi-deciduous forest. Vertical lines show standard deviation $(n=3)$.

Figura 2 - Variação no decorrer da manhã da eficiência quântica potencial do PSII $\left(F_{v} / F_{m}\right)$ de C. floribundus, A. graveolens e E. febrifuga crescendo em clareira de uma floresta semidecídua. As linhas verticais indicam o desvio-padrão $(n=3)$.

The decline of $\mathrm{F}_{\mathrm{v}} / \mathrm{F}_{\mathrm{m}}$ observed in the early species of forest succession (C. floribundus and A. graveolens) indicated photoinhibition. Chazdon et al. (1996) and Krause et al. (2001) observed a greater decline of $\mathrm{F}_{\mathrm{v}} / \mathrm{F}_{\mathrm{m}}$ in late species of forest succession than in early ones. It is important to note that these experiments were carried out with potted plants in artificial gaps (Chazdon et al., 1996) and with plants growing in full sun light conditions (Krause et al., 2001). Photoinhibition caused by excessive PPFD is a main cause of reduced $\mathrm{F}_{\mathrm{v}} / \mathrm{F}_{\mathrm{m}}$ under natural conditions (Long et al., 1994). Since excessive light could be caused by sunflecks, it is proposed that the cause of $\mathrm{F}_{\mathrm{v}} / \mathrm{F}_{\mathrm{m}}$ reduction in A. graveolens was the occurrence of sunfleck. Some studies have proposed that inactivation of PSII (low $\mathrm{F}_{\mathrm{v}} / \mathrm{F}_{\mathrm{m}}$ ) may confer photoprotection (Krause et al., 1990) or that it may be part of a mechanism adjusting PSII efficiency to the PPFD (Critchley, 1994).

Taking into account only the values of $\mathrm{F}_{\mathrm{v}} / \mathrm{F}_{\mathrm{m}}$, E. febrifuga would be the species with the highest potential photochemical capacity. However, this result was not necessarily related to a higher effective photochemical capacity, as observed through the results of $\Delta \mathrm{F} / \mathrm{F}_{\mathrm{m}}$, ETR, $\mathrm{qP}$ and $\mathrm{qN}$. C. floribundus and A. graveolens showed the highest values of $\Delta \mathrm{F} / \mathrm{F}_{\mathrm{m}}$, and qP (Figure 3a and 3c). The increase of light intensity caused a decrease of $\Delta \mathrm{F} / \mathrm{F}_{\mathrm{m}}$, mainly in E. febrifuga
(Figure 3a). This indicates a reduction of light energy utilization in the photochemical reactions of photosynthesis in those species (Maxwell \& Johnson, 2000).

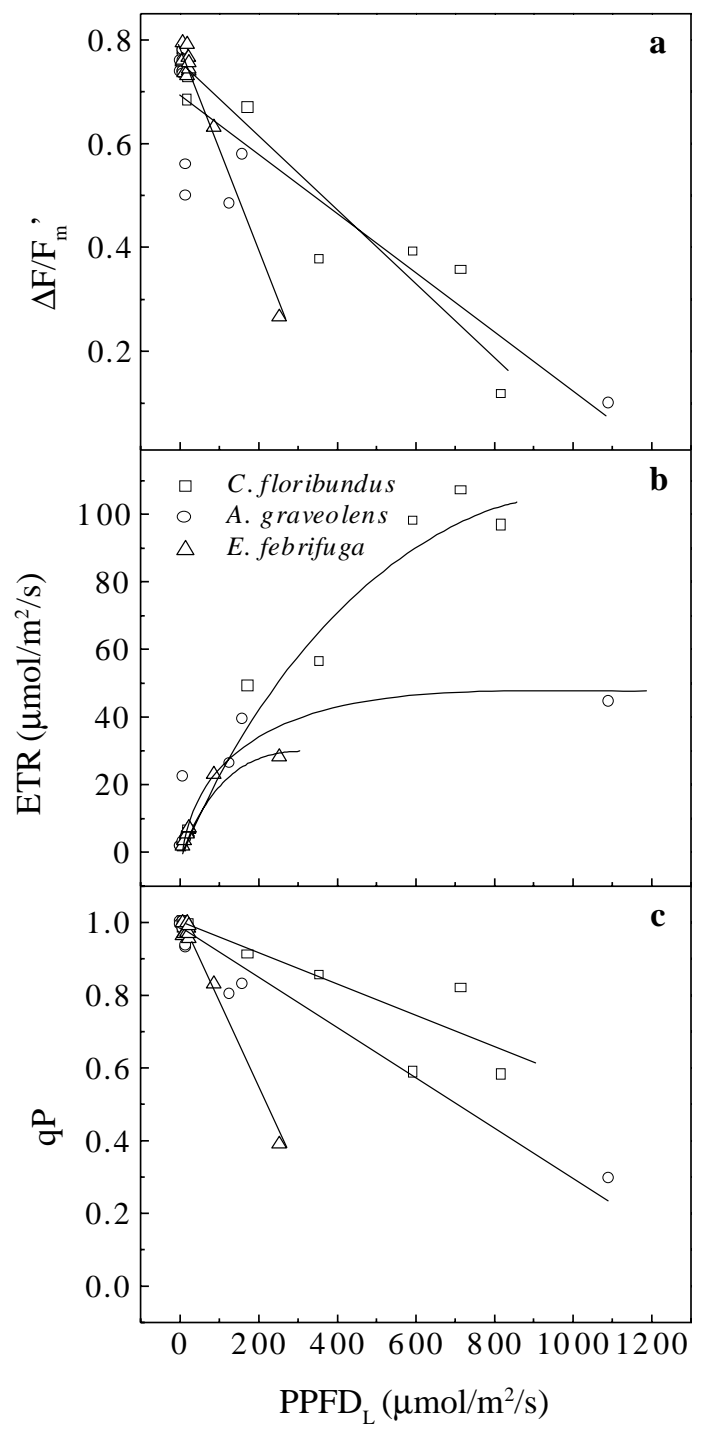

Figure 3- Light response curve of effective quantum efficiency of PSII $\left(\Delta F / F_{m}{ }^{\prime}, a\right)$, apparent el ectron transport rate $(E T R$, b) and photochemical quenching $(\mathrm{qP}, \mathrm{c})$ of $\mathrm{C}$. floribundus, A. graveolens and E. febrifuga growing in a gap of a semideciduous forest.

Figura 3 - Variação da eficiência quântica efetiva do PSII $\left(\Delta F / F_{m}^{\prime}, a\right)$, taxa aparente detransporte de el étrons ( $E T R$, b) eextinção fotoquímica da fluorescência (qP, c) em função da intensidade luminosa incidente na fol ha (PPFD $D_{\llcorner}$), em C. floribundus, A. graveolens eE . febrifuga crescendo em clareira de uma floresta semidecídua. 
The $\mathrm{qP}$ values decreased in relation to the increase of PPFD Although E. febrifuga had shown the highest $\mathrm{qP}$ decrease, it showed the highest $\mathrm{F}_{\mathrm{v}} / \mathrm{F}_{\mathrm{m}}$ values (Figure 2) and the lowest ETR values (Figure $3 \mathrm{~b}$ ). The $\mathrm{qP}$ values of $C$. floribundus and $A$. graveolens were almost twice the values of E. febrifuga at $\mathrm{PPFD}_{\mathrm{L}}$ of $250 \mu \mathrm{mol} / \mathrm{m}^{2} / \mathrm{s}$.

Although $C$. floribundus had showed the highest ETR values, no saturation was observed even under $\mathrm{PPFD}_{\mathrm{L}}$ of $800 \mu \mathrm{mol} / \mathrm{m}^{2} / \mathrm{s}$. On the other hand, A. graveolens showed ETR saturation in PPFD between 200 and $300 \mu \mathrm{mol} / \mathrm{m}^{2} / \mathrm{s}$. The lowest ETR values were measured in E. febrifuga (Figure $3 b$ ). Since ETR is calculated using the effective quantum efficiency of PSII photochemistry, this parameter is an indicator of overall photosynthetic capacity in vivo (Genty et al., 1989). According to this assumption, $C$. floribundus showed the highest photosynthetic capacity under the studied environmental condition.

Changes in chlorophyll fluorescence yield may be divided into two basic categories. Assuming that a physiologically intact photosynthetic organism can display a certain maximal fluorescence yield, any lowering of fluorescence related to this yield may be caused either by photochemical energy conversion in PSII (qP) or by an increase of non-radioactive de-excitation, involving heat formation or energy transfer to nonfluorescing photosystem I (qN) (Schreiber et al., 1998). Thus, the results of $\mathrm{qP}$ and $\mathrm{qN}$ showed that $C$. floribundus and $A$. graveolens were more efficient than $E$. febrifuga in the light energy conversion.

According to $\mathrm{qN}$ values, both pioneer ( $C$. floribundus) and early secondary (A. graveolens) species showed higher capacity to dissipate the excess of energy than the late successional species E. febrifuga. The higher the excess of energy was, the higher the $\mathrm{qN}$ was for $C$. floribundus and $A$. graveolens, contrarily to what was observed in qN values of E. febrifuga (Figure 4).

It has been reported a linear relationship between qN and excessive PPFD (Bilger et al., 1995; Schreiber et al., 1998). For plant survival, it is essential that the energy corresponding to the excessive PPFD be dissipated by special mechanisms, which prevent photodamage. In this sense, $\mathrm{qN}$ allows some insights into these mechanisms (Schreiber et al., 1994 and 1998).

In sun leaves that do not experience any environmental stresses, the combination of a high capacity for photosynthetic electron transport (indicated by a high
ETR) coupled with a high capacity for photoprotective thermal energy dissipation (indicated by a high qN), can apparently account for the removal of all energy absorbed by chlorophyll (Demmig-Adams \& Adams III, 1992). As C. floribundus showed the highest values of $\Delta \mathrm{F} / \mathrm{F}_{\mathrm{m}}$, $\mathrm{ETR}$, $\mathrm{qP}$ and $\mathrm{qN}$, this species could have more chances to grow in a forest gap, where there is high light intensity. On the other hand, shade-acclimated leaves have low capacities not only for photosynthetic electron transport but also for photoprotective responses such as thermal energy dissipation (Demmig-Adams \& Adams III, 1992). Under most conditions, the major contributor to $\mathrm{qN}$, is called high energy state quenching and is thought to be essential in protecting the leaf from light-induced damage (Maxwell \& Johnson, 2000). Since E. febrifuga showed these characteristics, its early classification as a late secondary species was supported.

The results of PCA analysis (Figure 5) showed a sharp difference between $C$. floribundus (pioneer species) and E. febrifuga (late secondary species). A. graveolens was located between the above species, but far from $E$. febrifuga. The decreasing order of importance of the parameters measured in order to separate the species in the first principal component was: $\Delta \mathrm{F} / \mathrm{F}_{\mathrm{m}}$, $, \mathrm{qP}, \mathrm{ETR}, \mathrm{qN}$ and $\mathrm{F}_{\mathrm{v}} / \mathrm{F}_{\mathrm{m}}$, according to principal component loadings $-0.5097,-0.5062,-0.5004$, -0.3703 and 0.3105 respectively.

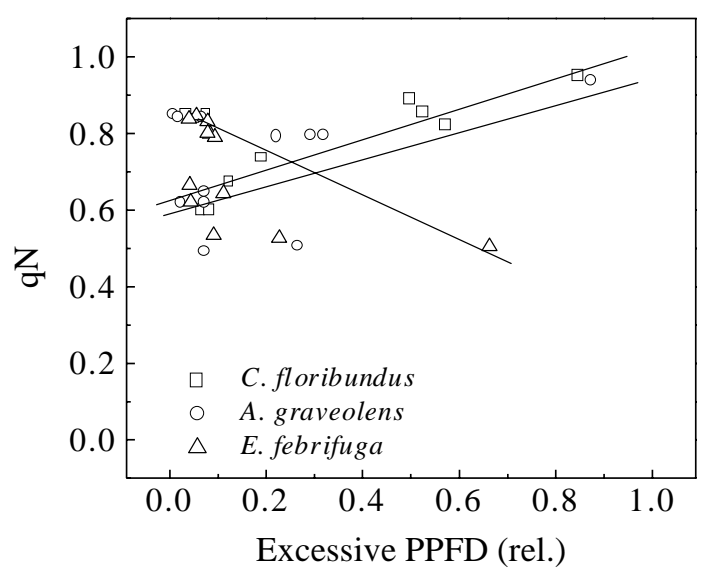

Figure 4 - Excessive-light response curve of nonphotochemical fluorescence quenching ( $q N)$ of C. floribundus, A. graveolens and E. febrifuga growing in a semi-deciduous forest gap.

Figura 4 - Variação da extinção não-fotoquímica da fluorescência (qN) em função do excesso de intensidade I uminosa, em C. floribundus, A. graveolens e E. febrifuga crescendo em clareira de uma floresta semidecídua.

R. Árvore, Viçosa-MG, v.28, n.1, p.21-27, 2004 


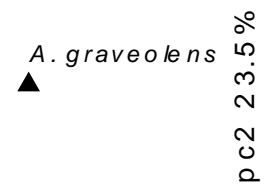

pc1 $76.5 \%$

E. febrifuga

C. flo rib und us

$\boldsymbol{A}$

Figure 5 - Ordination space generated by principal component analysis (PCA). All the parameters of chlorophyll fluorescence were considered. The decreasing order of importance of the measured parameters to separate the species was: $\Delta \mathrm{F} / \mathrm{F}{ }^{\prime}, \mathrm{qP}$, ETR, qN and $F_{/} / F_{m}$. The first principal component explained $76.5 \%$ of the total sample variance, whereas the second one explained $23.5 \%$ of the remained variance.

Figura 5 - Espaço de ordenação gerado pela análise de componentes principais. Todos os parâmetros de fluorescência da cl orofila foram considerados. A ordem decrescente de importância de cada parâmetro para a separação das espécies foi: $\Delta \mathrm{F} / \mathrm{F}_{\mathrm{m}}{ }^{\prime}, \mathrm{qP}, \mathrm{ETR}, \mathrm{qN}$ e $\mathrm{F}_{v} / \mathrm{F}_{\mathrm{m}}$. O primeiro componenteprincipal explicou 76,5\% da variância total da amostragem, enquanto o segundo componente explicou os $23,5 \%$ restantes.

PCA interpretation was carried out considering only the first principal component that explained $76.5 \%$ of total sample variance, indicating that the data structure was effectively summarized only in one dimension (McGarigal et al., 2000). Moreover, according to Broken Stick criterion used to determinate the importance of the principal components, only the first one was considered meaningful and was retained for interpretation (McGarigal et al., 2000).

According to $\mathrm{PCA}, \Delta \mathrm{F} / \mathrm{F}_{\mathrm{m}}$ ' was the principal parameter to differentiate the species followed by qP. In fact, pioneer species, such as $C$. floribundus, which grow under high light conditions, are expected to show higher energy harvesting and utilization than late successional species (Strauss-Debenedetti \& Bazzaz, 1996), as indicated by $\Delta \mathrm{F} / \mathrm{F}_{\mathrm{m}}$, and $\mathrm{qP}$ values respectively. This ecophysiological assumption was supported by the results of the significance of principal component loadings.

\section{CONCLUDING REMARKS}

The species C. floribundus, A. graveolens and E. febrifuga showed differences in chlorophyll fluorescence emission that may be related to the successional status of them. However, more experiments in other environmental conditions and with other species have to be carried out for improving and confirming the use of chlorophyll fluorescence as a helpful tool in order to differentiate successional classes. The results indicated that $\Delta \mathrm{F} / \mathrm{F}_{\mathrm{m}}$, was the most significant parameter to distinguish the species considered in this study. In addition, our data analyses support the classification of Gandolfi et al. (1995), and suggest that $\mathrm{F}_{\mathrm{v}} / \mathrm{F}_{\mathrm{m}}$ is not always a reliable and suitable parameter to distinguish successional classes at natural environment.

\section{ACKNOWLEDGEMENTS}

R.V.R. \& G.M.S. thank FAPESP (Fundação de Amparo a Pesquisa do Estado de São Paulo) and A.G.M. \& E.C.M. thank to CNPq (Conselho Nacional de Desenvolvimento Científico e Tecnológico) for the fellowships granted. 


\section{REFERENCES}

BILGER, W.; SCHREIBER, U.; BOCK, M. Determination of the quantum efficiency of photosystem II and nonphotochemical quenching of chlorophyll fluorescence in the field. Oecologia, v. 102, n. 4, p. 425-432, 1995.

CHAZDON, R. L. et al. Photosynthetic responses of tropical forest plants to contrasting light environments. In: MULKEY, S. S.; CHAZDON, R. L.; SMITH, A. P. Tropical forest plant ecophysiology. New York:Chapman \& Hall, 1996. p. 5-55.

CRITCHLEY, C. D1 Protein turnover: response to photodamage or regulatory mechanism? In: BAKER, N. R.; BOWYER, J. R. (Ed.) Photoinhibition of photosynthesis. Oxford:Bios Scientific, 1994. p. 195-204.

DEMMIG-ADAMS, B.; ADAMS III, W. W. Photoprotection and other responses of plants to high light stress. Annual Review of Plant Physiology and Plant Molecular Biology, v. 43, p. 599-626, 1992.

GANDOLFI, S.; LEITÃO FILHO, H. F.; BEZERRA, C. L. F. Levantamento florístico e caráter sucessional das espécies arbustivo-arbóreas de uma floresta mesófila semidecídua no município de Guarulhos. Revista Brasileira de Biologia, v. 55, n. 4, p. 753-767, 1995.

GENTY, B.; BRIANTAIS, J. M.; BAKER, N. R. The relationship between quantum yield of photosynthetic electron transport and quenching of chlorophyll fluorescence. Biochimica et Biophysica Acta, v. 990, n. 1, p. 87-92, 1989.

KRALL, J. P.; EDWARDS, G. E. Relationship between photosystem II activity and $\mathrm{CO}_{2}$ fixation in leaves. Physiologia Plantarum, v. 86, n. 1, p. 180-187, 1992.

KRAUSE, G. H. et al. On the mechanism of photoinhibition in chloroplasts: relationship between changes in fluorescence activity of photosystem II. Journal of Plant Physiology, v. 136, n. 4, p. 472-479, 1990.

KRAUSE, G. H. et al. Acclimation of tropical tree seedlings to excessive light in simulated tree-fall gaps. Plant, Cell and Environment, v. 24, n. 12, p. 1345-1352, 2001.
LONG, S. P.; HUMPHRIES, S.; FALKOWSKI, P. G. Photoinhibition of photosynthesis in nature. Annual Review of Plant Physiology and Plant Molecular Biology, v. 45, p. 633-662, 1994.

MANLY, B. F. J. Multivariate statistical methods - a primer. London:Chapman \& Hall, 1994. 214 p.

MAXWELL, K.; JOHNSON, G. N. Chlorophyll fluorescence - a practical guide. Journal of Experimental Botany, v. 51, n. 345, p. 659-668, 2000.

McGARIGAL, K.; CUSHMAN, S.; STAFFORD, S. Multivariate statistics for wildlife and ecology research. New York: Springer-Verlag, 2000. 283 p.

PICKETT, S. T. A.; OSTFELD, R. S. The shifting paradigm in ecology. In: KNIGHT, R. L.; BATES, J. F. (Ed.) A new century for natural resources management. Washington:Island Press, 1995. p. 261-278.

SCHREIBER, U.; BILGER, W.; NEUBAUER, C. Chlorophyll fluorescence as a non-intrusive indicator for rapid assessment of in vivo photosynthesis. In: SCHULZE, E. D.; CALDWELL, M. M. (Ed.) Ecophysiology of photosynthesis. Berlin Heidelberg New York:Springer Verlag, 1994. p. 49-70.

SCHREIBER, U. et al. Chlorophyll fluorescence as a diagnostic tool: basics and some aspects of practical relevance. In: RAGHAVENDRA, A.S. (Ed.)

Photosynthesis. Cambridge:Cambridge University Press, 1998. p. 320-336.

STRAUSS-DEBENEDETTI, S.; BAZZAZ, F. A. Photosynthetic characteristics of tropical trees along successional gradients. In: MULKEY, S. S.; CHAZDON, R. L.; SMITH, A. P. Tropical forest plant ecophysiology. New York:Chapman \& Hall, 1996. p. 162-186.

VAN KOOTEN, O.; SNEL, J. F. H. The use of chlorophyll fluorescence nomenclature in plant stress physiology. Photosynthesis Research, v. 25, n. 3, p. 147-150, 1990.

WEIS, E.; BERRY, J. A. Quantum efficiency of photosystem II in relation to "energy"-dependent quenching of chlorophyll fluorescence. Biochimica et Biophysica Acta, v. 894, n. 2, p. 198-208, 1987. 